\title{
Pengukuran Kinerja Keuangan PT Bank Panin Dubai Syariah Tbk Menggunakan Model Analisis DuPont System
}

\author{
Evan Stiawan $^{\bowtie}$, Vivi Esty Magfiroh \\ Institut Agama Islam Negeri Bengkulu \\ e-mail: evan@iainbengkulu.ac.id
}

\begin{abstract}
The purpose of this study is to study and compare financials for each financial period for three periods from PT Bank Panin Dubai Syariah Tbk. Period 2016 - 2018. The company's financial performance uses Return on Equity (ROE), Return on Investment (ROI), Total Asset Turnover (TAT), and Net Profit Margin (NPM). This study uses a comparative quantitative method using secondary data sources, namely the source of PT Bank Panin Dubai Syariah Tbk's financial reports since 2009. The research sample consisted of 12 financial statements selected by purposive sampling with a total of 48 data, and data analysis techniques using Two Ways ANOVA. The analysis showed a significant difference between finances based on the category of financial ratios over the three periods known from the significant value of 0,000 $<0.05$.
\end{abstract}

Keywords: Financial performance, Return on Equity (ROE), Return on Investment (ROI), Total Assets Turnover (TAT), Net Profit Margin (NPM)

\begin{abstract}
Abstrak
Tujuan penelitian ini adalah untuk mengetahui dan membandingkan kinerja keuangan tiap - tiap periode keuangan selama tiga periode dari PT Bank Panin Dubai Syariah Tbk. Periode 2016 2018. Kinerja keuangan perusahaan diukur menggunakan Return on Equity (ROE), Return on Investment (ROI), Total Assets Turnover (TAT), dan Net Profit Margin (NPM). Penelitan ini menggunakan metode kuantitatif komparatif dengan menggunakan sumber data sekunder yaitu dokumentasi dari laporan keuangan PT Bank Panin Dubai Syariah Tbk sejak periode 2009. Sampel penelitian terdiri dari 12 laporan keuangan yang dipilih secara purposive sampling dengan jumlah data pengamatan sebanyak 48 data serta teknik analisis data menggunakan Two Ways ANOVA. Hasil analisis menunjukan bahwa terdapat perbedaan yang signifikan kinerja keuangan berdasarkan kategori rasio keuangan selama tiga periode yang diketahui dari nilai signifikan sebesar $0.000<0.05$.
\end{abstract}

Keywords: Kinerja keungan, Return on Equity (ROE), Return on Investment (ROI), Total Assets Turnover (TAT), Net Profit Margin (NPM) 


\section{PENDAHULUAN}

Perekonomian di Indonesia yang terus berkembang pesat dengan munculnya berbagai perusahaan baru di berbagai bidang termasuk bank syariah di sektor keuangan. Munculnya bank syariah sebagai alternatif baru dalam pemenuhan kebutuhan masyarakat akan jasa keuangan yang sesuai prinsip ekonomi islam tentu dapat memicu persaingan usaha dengan berbagai pesaing yang berorientasi lokal maupun internasional. Sehingga suatu perusahaan dituntut untuk lebih efektif dan efisien dalam beroperasi untuk meningkatkan kemampuan perusahaan dalam menghasilkan keuntungan.

Untuk mencapai hal tersebut manajemen keuangan memberikan pengaruh langsung terhadap aktivitas dan eksistensi suatu perusahaan. Manajer keuangan diharuskan mampu untuk memahami kinerja keuangan perusahaan, melakukan kajian dan analisis yang dapat digunakan untuk membuat perencanaan, strategi baru, atau kebijakan-kebijakan yang berguna untuk mengembangkan dan mempertahankan operasional bank syariah secara optimal. Oleh karena itu, seorang manajer keuangan harus dapat menyajikan analisis keuangan untuk mengetahui kondisi dan perkembangan keuangan perusahaan.

Salah satu bentuk informasi yang dapat digunakan untuk mengetahui kondisi keuangan suatu perusahaan ialah dengan adanya laporan keuangan perusahaan. Laporan keuangan dilaporkan pada setiap akhir periode sebagai laporan pertanggung jawaban atas pengelolaan perusahaan. Di dalam laporan keuangan, tercatat seluruh aktivitas perusahaan selama satu periode. Sehingga perlu dilakukan suatu analisis kinerja keuangan yang salah satunya menggunakan model analisis DuPont system sebagai pengukur kinerja keuangan.

Model analisis DuPont system ini menggabungkan rasio - rasio aktivitas (total assets turnover) dan profit margin serta menunjukan bagaimana rasio - rasio tersebut berinteraksi untuk menunjukan profitabilitas serta pengembalian aktiva - aktiva (return on investmen) yang dimiliki perusahaan. Melalui model analisis DuPont ini juga dapat diketahui berbagai faktor yang menyebabkan naik turunnya kinerja keuangan suatu perusahaan. Analisis keuangan ini dapat digunakan untuk mengukur sejauh mana efektivitas perusahaan dalam memutar modal, sehingga analisis ini mencakup return on equity yang mengukur seberapa besar tingkat pengembalian ekuitas perusahaan dalam menghasilkan keuntungan. Dengan keuntungan tersebut perusahaan dapat menjamin pengembalian dana pinjaman atau pembiayaan. Hal ini karena seberapapun besarnya likuiditas perusahaan, jika perusahaan tersebut tidak dapat menggunakan modalnya secara efisien maka perusahaan tersebut akan mengalami kesulitan keuangan termasuk juga dalam pengembalian utang-utang perusahaan. Untuk melihat serta menilai tingkat efektivitas operasional perusahaan dalam penggunaan modal dan aktiva perusahaan tidak bisa hanya menggunakan kepekaan dan ketajaman para manajer secara kualitatif saja, tetapi menggunakan metode secara kuantitatif untuk dapat memperoleh dasar pertimbangan yang tepat dalam menyusun strategi atau menetapkan suatu kebijakan yang rasional.

\section{Laporan Keuangan}

Laporan keuangan adalah hasil dari proses akuntansi yang dapat digunakan sebagai alat komunikasi antara data keuangan atau aktivitas suatu perusahaan dengan pihak - pihak yang berkepentingan dengan data atau aktivitas perusahaan tersebut (Munawir, 2010). Laporan keuangan merupakan uraian pos-pos laporan keuangan yang menjadi sebuah informasi dan memperlihatkan hubungan bersifat signifikan baik berupa data kuantitatif maupun data nonkuantitatif yang digunakan untuk mengetahui keadaan 
keuangan lebih dalam dan penting dalam proses menghasilkan keputusan (Harahap, 2011). Laporan keuangan merupakan suatu pertanggung jawaban manajer atau pimpinan perusahaan atas pengelolaan perusahaan yang dipercayakan kepadanya, kepada pihak-pihak yang mempunyai kepentingan (stakeholder) di luar, dan pihak lainnya (Raharjo, 2005). Jadi, laporan keuangan yang dimaksudkan ialah laporan keuangan yang merupakan laporan pertanggungjawaban manajer dalam bentuk uraian pos-pos laporan keuangan yang telah diolah dengan proses akuntansi sehingga menjadi suatu informasi yang dapat digunakan sebagai alat komunikasi antar aktivitas suatu perusahaan dengan stakeholder-nya.

\section{Analisis Laporan Keuangan}

Analisis yaitu menguraikan suatu unit menjadi berbagai unit yang lebih kecil. Sedangkan laporan keuangan adalah neraca, laporan rugi laba, arus kas, dan dana. Dengan menggabungkan pengertian ini maka analisis laporankeuangan menjadi unit informasi yang lebih kecil dan melihat hubungannya yang bersifat signifikan atau mempunyai makna antara satu dengan yang lainnya baik antara data kuantitatif maupun data nonkuantitatif dengan tujuan untuk mengetahui kondisi keuangan lebih dalam yang sangat penting dalam proses pengambilan keputusan (Harahap, 2011). Setelah laporan keuangan disusun berdasarkan data yang relevan, serta dilakukan dengan prosedur akuntansi yang benar, kemudian melakukan penilaian atas laporan keuangan maka akan terlihat kondisi keuangan perusahaan pada periode tersebut.

Analisis laporan keuangan akan membantu dalam menilai prestasi manajemen dimasa lalu dan prospeknya di masa depan. Terdapat dua metode dalam menganalisis laporan keuangan yang dapat digunakan (Munawir, 2010), yaitu analisis horisontal dan analisis vertikal.

\section{Model Analisis DuPont System}

Model analisis DuPont system merupakan analisa yang mencakup seluruh rasio aktivitas dan margin keuntungan atas penjualan untuk menunjukan bagaimana rasio ini mempengaruhi profitabilitas (Brigham \& Houston, 2012). Model analisis DuPont system menyangkut rasio aktivitas dan rasio profitabilitas, dimana rasio aktifitas dan rasio profitabilitas akan dikombinasikan untuk dapat melihat kinerja suatu perusahaan. Dari Model analisis DuPont system ini kita dapat diketahui keefektivan penggunaan aktiva perusahaan. Model analisis DuPont system memperlihatkan bagaimana perputaran total aktiva dan profit margin dikombinasikan untuk menentukan return on investment, dan bagaimana perputaran modal perusahaan dalam menghasilkan keuntungan.

\section{Return on Equity (ROE)}

Hasil pengembalian ekuitas (return on equity) atau rentablitas modal sendiri merupakan rasio untuk mengukur laba bersih setelah pajak dengan modal sendiri. Rasio ini menunjukan efisiensi penggunaan modal sendiri. Semakin tinggi rasio ini, semakin baik. Artinya posisi pemilik perusahaan semakin kuat, demikian pula sebaliknya (Kasmir, 2015). Berikut ini adalah cara untuk mencari hasil pengembalian ekuitas dengan pendekatan model analisis DuPont system yaitu sebagai berikut (Asnaini, 2012):

$$
R O E=\frac{E A T}{\text { Total Equity }} \times 100 \%
$$

\section{Return on Investment (ROI)}

ROI juga merupakan suatu ukuran efektivitas manajemen dalam mengelola investasinya. Semakin kecil (rendah) rasio ini, semakin kurang baik, demikian pula sebaliknya (Kasmir, 2015). Artinya rasio ini digunakan untuk mengukur efektivitas dari keseluruhan operasional perusahaan. Di samping itu, hasil pengembalian investasi 
menunjukkan produktivitas dari seluruh dana perusahaan. Baik modal pinjaman maupun modal sendiri Berikut ini adalah cara mencari hasil pengembalian investasi (ROI) (Asnaini, 2012):

$$
R O I=\frac{E A T}{\text { Total Assets }} \times 100 \%
$$

\section{Total Asset Turnover (TAT)}

Perputaran total aktiva adalah suatu rasio yang menunjukan tingkat efisiensi perusahaan menggunakan aktivanya di dalam menghasilkan volume penjualan tertentu (Keown dkk., 2008). Perhitungan rasionya dapat dihitung seperti di bawah ini (Asnaini, 2012):

$$
\text { TAT }=\frac{\text { NetSales }}{\text { Total Assets }} \times 1 \text { time }
$$

\section{Net Profit Margin}

Net profitmargin inimenunjukan berapa besar keuntungan bersih yang diperoleh perusahaan (Sugiono \& Untung, 2016). Margin laba atas penjualan merupakan rasio keuangan yang digunakan untuk mengukur margin laba atas penjualan. Cara pengukuran rasio ini adalah dengan membandingkan laba bersih setelah pajak dengan penjualan bersih. Untuk mengukur margin laba bersih dapat dilakukan denga rumus (Asnaini, 2012):

$$
N P M=\frac{E A T}{\text { Net Sales }} \times 100 \%
$$

\section{Kinerja Keuangan Perusahaan}

Penilaian kinerja perusahaan merupakan suatu penilaian secara berkala mengenai operasional perusahaan sebagai alat pengendalian manajemen perusahaan yang digunakan sebagai pemicu dari tercapainya suatu strategi perusahaan. Untuk menilai efektifitas suatu perusahaan dalam menghasilkan laba dapat dilakukan dengan menganalisis laporan keuangan perusahaan untuk mengetahui bagaimana kinerja keuangan perusahaan tersebut. Suwarjeni mengungkapkan bahwa kinerja adalah hasil dari evaluasi terhadap pekerjaan yang telah selesai dilakukan, hasil pekerjaan tersebut dibandingkan dengan kriteria yang ditetapkan bersama karena setiap pekerjaan yang telah selesai harus dilakukan pengukuran secara periodik (Suwarjeni, 2017). Kinerja keuangan itu sendiri adalah efektifitas manajemen perusahaan dalam memfungsikan dan memberdayakan segala unsur yang ada di perusahaan. Sedangkan menurut Fahmi (2014), kinerja keuangan ialah suatu analisis yang dilakukan untuk melihat sejauh mana perusahaan telah malaksanakan dengan menggunakan aturan-aturan pelaksanaan keuangan secara baik dan benar. Hal ini dilakukan dengan membuat laporan keuangan yang telah memenuhi standard dan ketentuan SAK (Standar Akuntansi Keuangan) atau GAAP (General Accepted Accounting Principle), dan lainnya (Fahmi, 2014). Kinerja keuangan itu sendiri merupakan efektivitas manajemen perusahaan dalam memberdayakan segala unsur yang ada di perusahaan.

\section{Hipotesis}

$\mathrm{H}_{1}$ : Return on Equity (ROE) berkorelasi positif dengan kinerja keuangan

$\mathrm{H}_{2}$ : Return on Investment (ROI) berkorelasi positif dengan kinerja keuangan

$\mathrm{H}_{3}$ : Total Asset Turnover berkorelasi positif dengan kinerja keuangan

$\mathrm{H}_{4}$ : Net Profit Margin (NPM) berkorelasi positif dengan kinerja keuangan 


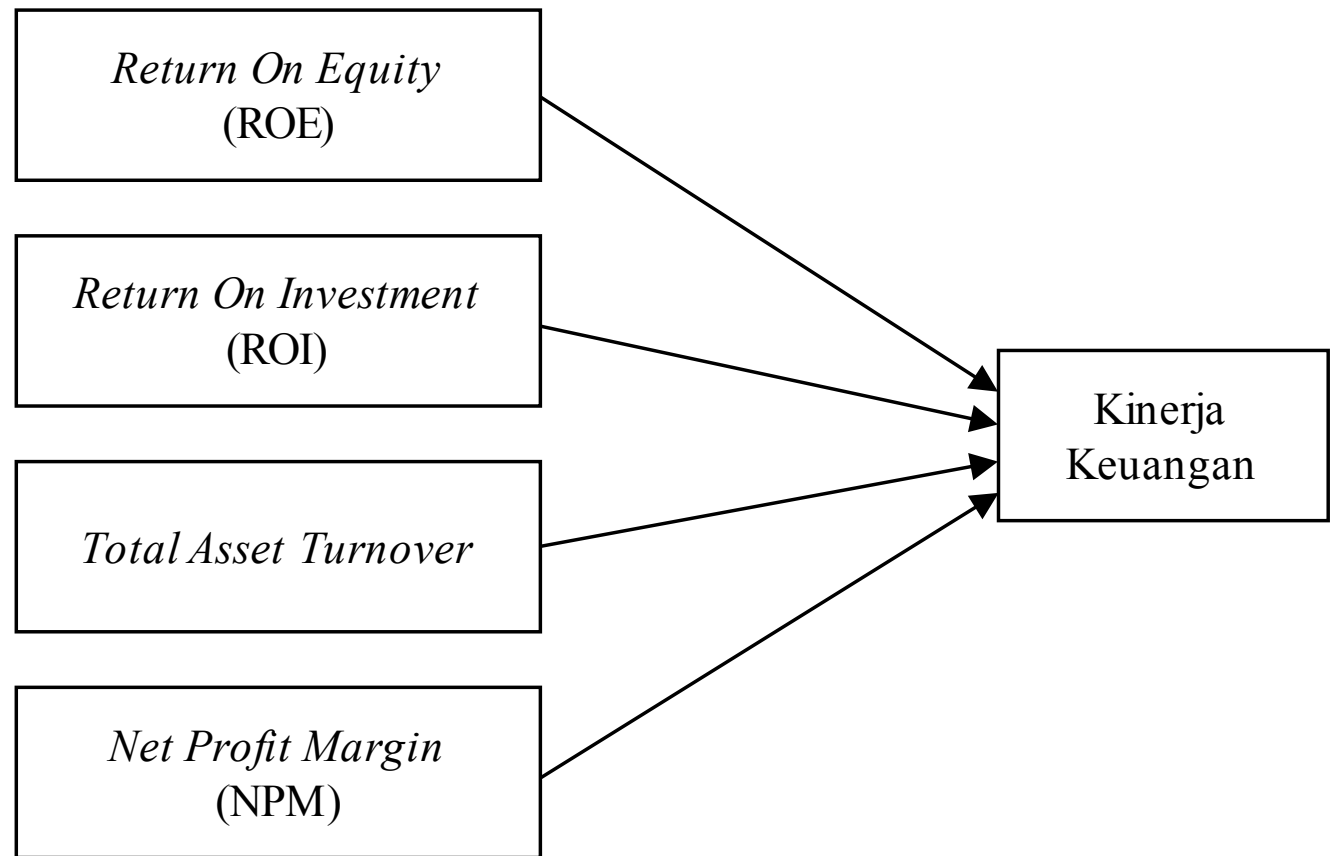

Gambar 1. Model Penelitian

\section{METODE PENELITIAN}

Penelitian ini menggunakan pendekatan kuantitatif komparatif. Dalam penelitian ini akan menjelaskan dan menghitung rasio keuangan (Bungin, 2009), yang akan membandingkan kinerja keuangan PT Bank Panin Dubai Syariah Tbk mulai dari tahun 2016 sampai dengan tahun 2018.

Adapun Populasi dalam penelitian ini yaitu seluruh laporan keuangan PT Bank Panin Dubai Syariah Tbk yang mulai beroperasi sebagai bank umum syariah sejak tahun 2009. Laporan keuangan yang digunakan dalam penelitian ini yaitu 12 laporan keuangan per tiga bulan PT Bank Panin Dubai Syariah yang dipilih dengan menggunakan teknik purposive sampling dengan jumlah pengamatan sebanyak 48 data. Purposive sampling merupakan teknik penentuan sampel dengan pertimbangan tertentu (Sugiyono, 2014a). Sampel diambil dari beberapa kriteria pertimbangan: (1) laporan keuangan PT Bank Panin Dubai Syariah yang digunakan dalam penelitian ialah laporan keuangan setelah PT Bank Panin Dubai Syariah terdaftar di Bursa Efek Indonesia yaitu sejak tahun 2014, (2) laporan keuangan PT Bank Panin Dubai Syariah setelah terdaftar di Bursa Efek Indonesia dapat diteliti setelah 2 tahun terdaftar, dan (3) mengambil laporan keuangan teraktual dari 3 tahun terakhir. Sumber data yang digunakan dalam penelitian ini ialah data sekunder berupa dokumentasi laporan keuangan yang diarsipkan. Adapun variabel yang digunakan dalam penelitian ini yaitu total asset turnover, net profit margin, return on investment, return on equity dan kinerja Keuangan

Analisis data menggunakan aplikasi SPSS 17. Tahapan analisis data yang dilakukan yaitu uji kualitas data dengan melakukan uji normalitas yaitu uji dengan menggunakan uji One-Sample Kolmogorov - Smirnov. Dengan kriteria kenormalan data nilai signifikan $>0.05(\mathrm{Sig}>0.05)$ (Noor, 2014). Uji homogenitas dengan metode yang digunakan yaitu Levene Test dengan test homogenity of variance (Sugiyono, 2014b). Uji asumsi klasik dengan menggunakan uji autokorelasi yaitu dengan menggunakan uji Durbin Watson (DW) (Wijaya, 2011), uji multikolinearitas dengan menggunakan Variance Inflation Factor (VIF) dan Tolerance (Wijaya, 2011), dan 
uji heteroskedatisitas dengan menggunakan uji Glejser. Selanjutnya uji hipotesis dengan menggunakan ANOVA dua jalur (Two Ways ANOVA). Two Ways ANOVA digunakan untuk menguji hipotesis perbandingan lebih dari dua sampel dan setiap sampel terdiri atas dua jenis atau lebih secara bersama-sama (Riduwan, 2018). Untuk menentukan uji Two ways ANOVA, digunakan kriteria berikut: nilai signifikan lebih besar dari 0.05 ( $\mathrm{Sig}>$ 0.05 ) berarti tidak terdapat perbedaan antar kategori. Jika nilai signifikan lebih kecil dari 0.05 (Sig < 0.05) maka terdapat perbedaan antar kategori yang dibandingkan.

\section{HASIL DAN PEMBAHASAN}

\section{Uji Kualitas Data}

Tabel 1. Hasil Uji Normalitas

\begin{tabular}{cccc}
\hline Variabel & $\begin{array}{c}\text { Nilai } \\
\text { Signifikan }\end{array}$ & Kriteria & Keterangan \\
\hline TAT & 0.365 & $>0.05$ & Normal \\
ROE & 0.849 & $>0.05$ & Normal \\
ROI & 0.891 & $>0.05$ & Normal \\
NPM & 0.727 & $>0.05$ & Normal \\
\hline
\end{tabular}

Sumber: Data yang diolah

Berdasarkan kenormalan data pada Tabel 1, dapat disimpulkan bahwa data penelitian berdistribusi normal dan berarti sampel yang diambil dalam penelitian ini berasal dari populasi yang sama.

Tabel 2. Hasil Uji Homogenitas

\begin{tabular}{cccl}
\hline Variabel & $\begin{array}{c}\text { Nilai } \\
\text { Signifikan }\end{array}$ & Kriteria & Keterangan \\
\hline TAT & 0.128 & $>0.05$ & Homogen \\
ROE & 0.142 & $>0.05$ & Homogen \\
ROI & 0.132 & $>0.05$ & Homogen \\
NPM & 0.127 & $>0.05$ & Homogen \\
\hline
\end{tabular}

Sumber: Data yang diolah

Berdasarkan Tabel 2, dapat diketahui bahwa semua data sampel memiliki varians yang sama.

\section{Uji Asumsi Klasik}

Uji autokorelasi bertujuan untuk mengetahui ada atau tidaknya korelasi antara variabel pengganggu pada periode waktu tertentu dengan periode waktu sebelumnya. Tabel 3 menampilkan hasil uji Durbin Watson untuk menguji masalah autokorelasi:

Tabel 3. Hasil Uji Autokorelasi

\begin{tabular}{llllll}
\hline Model & Variabel & Method & $\begin{array}{l}\text { Durbin }- \\
\text { Watson }\end{array}$ & Kriteria & Keterangan \\
\hline 1 & TAT & Enter & 0.503 & diantara & tidak \\
& ROE & & & -2 dan & terdapat \\
& ROI & & & +2 & gejala \\
& NPM & & & & autokorelasi
\end{tabular}

Sumber: Data yang diolah

Berdasarkan Tabel 3, dapat diketahui bahwa nilai Durbin Watson sebesar 0.503. Sesuai dengan kriteria angka D-W di antara -2 sampai +2 berarti tidak ada gejala autokorelasi, hasil ini menyatakan bahwa tidak terdapat gejala autokorelasi antar variabel.

Metode yang digunakan untuk mendeteksi adanya masalah multikolinieritas ini dengan menggunakan metode Variance Inflation Factor (VIF) dan Tolerance. Semakin kecil nilai VIF dan Tolerance maka semakin mendekati terjadinya multikolinieritas.

Tabel 4. Hasil Uji Multikolinieritas

\begin{tabular}{cccc}
\hline \multirow{2}{*}{ Variabel } & \multicolumn{2}{c}{ Colinearity Statistics } & \\
\cline { 2 - 3 } & Tolerance & VIF & Keterangan \\
\hline TAT & 0.399 & 2.507 & Bebas multikolinieritas \\
ROE & 0.718 & 2.917 & Bebas multikolinieritas \\
ROI & 0.343 & 2.917 & Bebas multikolinieritas \\
NPM & 0.343 & 1.394 & Bebas multikolinieritas \\
\hline
\end{tabular}

Sumber: Data yang diolah

Berdasarkan Tabel 4 di atas bahwa nilai Tolerance dan VIF tiap variabel telah memenuhi kriteria, sehingga dapat disimpulkan bahwa variabel penelitian tidak mengalami masalah multikolinieritas.

Variabel yang baik untuk diteliti seharusnya tidak mengalami masalah heteroskedastisitas. Dan untuk mendeteksi apakah terjadi masalah heteroskedastsitas dalam variabel penelitian ini dapat dilakukan dengan menggunakan Uji Glejser yaitu 
Pengukuran Kinerja Keuangan PT Bank Panin ... (Evan Stiawan, Vivi Esty Magfiroh)

meregresikan nilai absolut residual dari variabel independent.

Tabel 5. Hasil Uji Heteroskedastisitas

\begin{tabular}{cccc}
\hline Variabel & $\begin{array}{c}\text { Nilai } \\
\text { Signifikan }\end{array}$ & Kriteria & Keterangan \\
\hline TAT & 0.125 & $>0.05$ & Bebas heteroskedastisitas \\
ROE & 0.218 & $>0.05$ & Bebas heteroskedastisitas \\
ROI & 0.325 & $>0.05$ & Bebas heteroskedastisitas \\
NPM & 0.156 & $>0.05$ & Bebas heteroskedastisitas \\
\hline
\end{tabular}

Sumber: Data yang diolah

Berdasarkan Tabel 5 dapat disimpulkan bahwa data setiap variabel penelitian bebas dari masalah heteroskedastisitas.

\section{Uji Hipotesis}

Tujuan pengujian hipotesis dalam penelitian ini ialah untuk membuktikan secara statistik apakah terdapat perbedaan secara signifikan kinerja keuangan PT Bank Panin Dubai Syariah Tbk. selama tiga periode yaitu sejak periode 2016 hingga periode 2018 dilihat dari perhitungan rasio keuangan dalam analysis $d u$ pont system. Variabel dalam penelitian ini yang mewakili kinerja keuangan PT Bank Panin Dubai Syariah Tbk adalah Return on Equity (ROE), Return on Investment (ROI), Total Assets Turnover (TAT), dan Net Profit Margin (NPM). Hasil pengujian hipotesis dapat dilihat dalam tabel berikut:
Tabel 6. Hasil Uji Hipotesis

\begin{tabular}{cccc}
\hline Kategori & $\begin{array}{c}\text { Nilai } \\
\text { Signifikan }\end{array}$ & Kriteria & Keterangan \\
\hline Rasio & 0.000 & $<0.05$ & $\begin{array}{c}\text { Berbeda signifikan } \\
\text { Tidak berbeda } \\
\text { signifikan }\end{array}$ \\
Periode & 0.136 & $>0.05$ & \\
\hline Sumber: Data yang diolah & &
\end{tabular}

Berdasarkan Tabel 6 yang menunjukan bahwa diperoleh nilai signifikan dari kategori periode sebesar 0.136 lebih besar dari 0.05 (signifikan $0.136>0.05$ ). Hal ini menunjukkan bahwa tidak terdapat pengaruh langsung periode keuangan terhadap hasil pengukuran kinerja keuangan PT Bank Panin Dubai Syariah Tbk menggunakan analisis DuPont system. Kinerja keuangan dihitung dinyatakan dalam rasio yang sama setiap periodenya, yaitu ROE, ROI, TAT, dan NPM.

Dilihat dari nilai signifikan pada kategori rasio sebesar 0.000 lebih kecil dari 0.05 (Sig $0.000<0.05)$ sehingga dapat diambil kesimpulan bahwa terdapat pengaruh langsung kategori rasio keuangan terhadap kinerja keuangan PT Bank Panin Dubai Syariah Tbk dinilai dari hasil rasio keuangan yang diperoleh dari analisis DuPont system. Artinya, terdapat perbedaan nilai mean kinerja keuangan berdasarkan pengelompokan rasio keuangan. Hal ini dikarenakan hasil perhitungan rasio keuangan menggunakan analisis DuPont system dengan variabel yang mewakili kinerja keuangan yang berubah ubah sesuai dengan kondisi keuangan yang terjadi pada periode tersebut.

Tabel 7. Hasil Analisis DuPont terhadap ROE, ROI, TAT, dan NPM

Periode Maret - Desember 2016

\begin{tabular}{lccccc}
\hline \multirow{2}{*}{ Periode } & \multicolumn{4}{c}{ Rasio Keuangan } \\
\cline { 3 - 6 } & ROE $(\%)$ & ROI $(\%)$ & TAT (time) & NPM (\%) \\
\hline \multirow{2}{*}{2016 Maret } & 0.230 & 0.038 & 0.026 & 1.471 \\
\multicolumn{2}{c}{ Ruta - Rata } & 0.839 & 0.126 & 0.044 & 2.857 \\
& September & 1.474 & 0.213 & 0.063 & 3.398 \\
Desember & 1.645 & 0.223 & 0.079 & 2.819 \\
\hline
\end{tabular}

Sumber: Data yang diolah 
Tabel 8. Hasil Analisis DuPont terhadap ROE, ROI, TAT, dan NPM

Periode Maret - Desember 2017

\begin{tabular}{|c|c|c|c|c|c|}
\hline \multirow{2}{*}{\multicolumn{2}{|c|}{ Periode }} & \multicolumn{4}{|c|}{ Rasio Keuangan } \\
\hline & & ROE (\%) & ROI (\%) & TAT (time) & NPM $(\%)$ \\
\hline \multirow{4}{*}{2017} & Maret & 1.036 & 0.142 & 0.021 & 6.659 \\
\hline & Juni & 1.215 & 0.154 & 0.041 & 3.755 \\
\hline & September & 1.219 & 0.161 & 0.065 & 2.474 \\
\hline & Desember & -353.342 & -11.227 & -0.092 & -122.112 \\
\hline \multicolumn{2}{|c|}{ Rata - Rata } & -87.468 & -2.692 & -0.008 & -27.306 \\
\hline
\end{tabular}

Sumber: Data yang diolah

Tabel 9. Hasil Analisis DuPont terhadap ROE, ROI, TAT, dan NPM

Periode Maret - Desember 2018

\begin{tabular}{lccccc}
\hline \multirow{2}{*}{ Periode } & \multicolumn{4}{c}{ Rasio Keuangan } \\
\cline { 3 - 6 } & ROE $(\%)$ & ROI $(\%)$ & TAT (time $)$ & NPM $(\%)$ \\
\hline \multirow{2}{*}{2018} & Maret & 0.251 & 0.047 & 0.018 & 2.660 \\
\multicolumn{2}{c}{ Juni } & 0.485 & 0.094 & 0.035 & 2.677 \\
& September & 0.709 & 0.145 & 0.056 & 2.599 \\
Rata - Rata & 1.246 & 0.237 & 0.068 & 3.471 \\
\hline
\end{tabular}

Sumber: Data yang diolah

Tabel 7, 8, dan 9 menunjukkan perbandingan hasil perhitungan analisis DuPont system pada ROE, ROI, TAT, dan NPM selama periode 2016 - 2018. Rata rata ROE selama periode 2016 - 2018 dengan perentase sebesar $1.047 \%$ pada periode 2016 lebih unggul dibandingkan persentase perolehan ROE pada periode 2018 sebesar $0.672 \%$, bahkan mengalami kerugian pada periode 2017 sehingga perolehan nilai ROE menurun menjadi $-27.648 \%$. Nilai ROE yang menurun dari 2016 ke 2017 menunjukkan penurunan kinerja keuangan PT Bank Panin Dubai Syariah Tbk pada periode tersebut. Kemudian nilai ROE dari periode 2017 2018 menunjukkan peningkatan, yang berarti kemampuan perusahaan dalam menghasilkan pengembalian ekuitas dan efisiensi penggunaan modal sendiri mengalami peningkatan.

Rata - rata ROI selama periode 20162018 menunjukan kondisi keuangan yang fluktuatif, di mana persentase perolehan ROI sebesar $0.150 \%$ pada periode $2016,-2.692 \%$ pada periode 2017 , dan $0.130 \%$ pada periode 2018. Hal ini menunjukan pada periode 2016 sampai periode 2017 kemampuan perusahaan dalam menghasikan keuntungan dari investasi mengalami penurunan. Kemudian pada periode 2017 sampai 2018 kemampuan perusahaan dalam menghasilkan keuntungan dari investasi kembali meningkat.

Selanjutnya dapat dilihat dari rata-rata TAT periode 20160.053 kali lebih efektif dalam meningkatkan efisiensi penggunaan aktiva perusahaan untuk meningkatkan volume penjualan daripada periode 2017 sebesar -0.008 kali dan 0,044 kali pada periode 2018. Nilai assets turnover dari ketiga periode tersebut mengalami perubahan terus menerus (fluktuatif). Hal ini menunjukkan bahwa efektifitas perusahaan dalam menghasilkan penjualan juga mengalami fluktuasi. Dimana efektivitas penjualan dapat dipengaruhi 
oleh efektivitas program pemasaran yang dilakukan perusahaan, dan kemampuan daya saing perusahaan dalam meraih pasar yang ada.

Nilairata-rataNPMperiode2016sebesar $2.636 \%$, 2017 senilai $-27.306 \%$, dan periode 2018 2.851\%. Hal ini menunjukkan bahwa kemampuan perusahaan dalam menghasilkan keuntungan dari penjualan bersih menurun dari periode 2016 sampai periode 2017. Namun, mengalami peningkatan dari periode 2017 sampai periode 2018 .

Berdasarkan perbandingan ketiga periode keuangan dapat dikatakan bahwa periode 2016 PT Bank Panin Dubai Syariah Tbk. memiliki kinerja keuangan yang paling bagus dilihat dari perolehan ROE, ROI, dan TAT. Sedangkan pada periode 2018, kinerja keuangan yang paling bagus terlihat dari perolehan NPM. Pada periode 2017, terjadi penurunan kinerja keuangan. Hal ini terjadi karena adanya kerugian yang dialami perusahaan akibat adanya beban kerugian penurunan nilai. Kinerja keuangan periode 2017 mengalami penurunan dilihat dari seluruh rasio keuangan meliputi ROE, ROI, TAT, dan NPM. Pada periode 2018, pihak bank melakukan pemulihan kerugian penurunan nilai untuk mengatasi kerugian tersebut sehingga kinerja keuangan kembali membaik. Hal ini ditandai dengan meningkatnya kemampuan perusahaan dalam menghasilkan keuntungan dari penjualan bersih perusahaan dengan perolehan NPM tertinggi dalam tiga periode keuangan.

\section{SIMPULAN DAN SARAN}

Berdasarkan hasil penelitian dan pembahasan, dapat diambil kesimpulan dari rata-rata Return on Equity (ROE) PT Bank Panin Dubai Syariah Tbk mampu menghasilkan tingkat pengembalian ekuitas terhadap laba bersih yang bagus di tahun 2016 dibanding tahun 2017 dan tahun 2018.
Tingkat pengembalian ekuitas tahun 2016 sebesar 1.047\% lebih tinggi dari tahun 2017 sebesar $-87.468 \%$ dan tahun 2018 sebesar $0.672 \%$. ROE sebesar $1.047 \%$ di tahun 2016 dapat diartikan setiap satu rupiah ekuitas yang ada di tahun 2016 dapat menghasilkan laba bersih sebesar $1.047 \%$. Dilihat dari rata-rata Return on Investment (ROI), PT Bank Panin Dubai Syariah Tbk mampu menghasilkan tingkat efektivitas aktiva terhadap laba bersih yang bagus pada tahun 2016 dibanding tahun 2017 dan 2018. Tingkat efektivitas aktiva tahun 2016 sebesar $0.150 \%$ lebih efektif dari tahun 2017 sebesar $-2.692 \%$ dan tahun 2018 sebesar $0.130 \%$. ROI sebesar $0.150 \%$ di tahun 2016 ini dapat diartikan setiap satu rupiah aktiva yang ada di tahun 2016 dapat menghasilkan laba bersih sebesar $0.150 \%$. Dilihat dari rata-rata Total Assets Turnover (TAT), PT Bank Panin Dubai Syariah Tbk mampu menghasilkan tingkat efisiensi perputaran aktiva terhadap penjualan yang bagus di tahun 2016 dibanding tahun 2017 dan 2018. Tingkat perputaran aktiva tahun 2016 sebesar 0.053 kali lebih efisien dari tahun 2017 sebesar -0.008 kali dan tahun 2018 sebesar 0.044 kali. TAT sebesar 0.053 kali di tahun 2016 dapat diartikan setiap satu rupiah aktiva yang ada dan diopersionalkan di tahun 2016 dapat menghasilkan penjualan sebanyak 0.053 kali. Dilihat dari Net Profit Margin (NPM), PT Bank Panin Dubai Syariah Tbk mampu menghasilkan tingkat efektivitas penjualan dalam menghasilkan laba bersih yang cukup efektif di tahun 2018 sebesar $2.851 \%$ yang artinya setiap satu rupiah penjualan dapat menghasilkan laba bersih sebesar $2.851 \%$. Tingkat efektivitas tersebut mengalami kenaikan dari $2.636 \%$ di tahun 2016 dan $-27.306 \%$ di tahun 2017 .

Dengan demikian PT. Bank Panin Dubai Syariah Tbk telah mampu mengembalikan kinerja keuangan perusahaan dalam kondisi yang baik terlihat dari kenaikan NPM perusahaan. Pada periode yang akan datang, PT. Bank Panin Dubai Syariah Tbk dapat 
terus meningkatkan kinerja keuangannya melalui peningkatan perolehan ROE, ROI, dan TAT perusahaan. Dengan demikian perusahaan dapat terus berkembang dalam kondisi kinerja keuangan yang baik dan menjaga eksistensinya.

\section{REFERENSI}

Asnaini, A., Stiawan, E., \& Asriani, W. (2012). Manajemen Keuangan. Yogyakarta: Teras.

Bungin, B. (2010). Metodologi Penelitian Kuantitatif. Jakarta: Kencana.

Brigham, E. F., \& Houston, J. F. (2012). Dasar-dasar Manajemen Keuangan. Terjemahan oleh Ali Akbar Yulianto. Jakarta: Salemba Empat.

Fahmi, I. (2014). Analisis Kinerja Keuangan. Bandung: Alfabeta.

Harahap, S. S. (2011). Analisis Kritis Atas Laporan Keuangan. Jakarta: Raja Grafindo.

Kasmir. (2015). Analisis Laporan Keuangan. Jakarta: Rajawali Perss.

Keown, A. J., Martin, J. D., Petty, J. W., \& Scott, D. F. (2008). Manajemen Keuangan. Terjemahan oleh Marcus Prihminto. Jakarta: Indeks.

Noor, Noor, J. (2014). Analisis Data Penelitian Ekonomi dan Manajemen. Jakarta: PT Gramedia.

Riduwan. (2018). Dasar - Dasar Statistik. Bandung: Alfabetha.

Munawir, S. (2010). Analisa Laporan Keuangan. Edisi Keempat. Yogyakarta: Liberty.

Sugiono, A., \& Untung, E. (2016). Panduan Praktis Dasar Analisa Laporan Keuangan. Jakarta: PT Raja Grasindo.

Sugiyono. (2014a). Metode Penelitian Kombinasi. Bandung: Alfabeta.
Sugiyono. (2014b). Statistika Untuk Penelitian. Bandung: Alfabetha.

Sujarweni, W. (2017). Analisis Laporan Keuangan Teori Aplikasi dan Analisis. Yogyakarta: Pustaka Baru Press.

Wijaya, T. (2011). Cepat Menguasai SPSS 19 untuk Olah dan Interpretasi Data Penelitian. Yogyakarta: Cahaya Atma. 